Столар Вадим Михайлович аспірант кафедри державного управління Київського національного університету імені Тараса Шевченка, вул. Володимирська, 64/13, м. Київ, 01601, тел.: (044) 239-31-12, e-mail: sto-nauk@ukr.net, https://orcid.org/0000-0003-1493-6830

\title{
ПРИНЦИПИ ВДОСКОНАЛЕННЯ СИСТЕМИ ДЕРЖАВНИХ ПОСЛУГ (МІЖНАРОДНИЙ ДОСВІД)
}

Анотація. Показано, що у сучасних моделях державного управління, які спираються на ідею сервісної держави, зростає роль інституту державних послуг. Зазначається, що сучасні уряди шукають різноманітні способи удосконалення процесу надання державних послуг, а держава Україна шукає свій шлях модернізації державного управління та удосконалення системи державних послуг. Автор застерігає, що успішний варіант механізму надання державних послуг в окремій країні не завжди є успішним в іншій країні. Тому державна реформа адміністративних послуг в Україні повинна не сліпо копіювати зарубіжний досвід, але враховувати основоположні принципи модернізації та ретельно аналізувати наслідки. Автор переконаний, що досвід країн $з$ усталеними демократичними цінностями $є$ дуже важливим для України. Адже, у таких політичних системах надається особлива роль інституту державних послуг, а відносини між державою та суспільством $\epsilon$ прозорими та рівноправними. У цьому зв'язку, автором обрано практики реформування державних послуг у США, Канаді, Австралії, Новій Зеландії, країнах Західної Європи. Здійснено теоретичне дослідження сутності поняття «послуга». Проаналізовано принципи та методи вдосконалення державних послуг. Виокремлено такі основоположні принципи реформування системи державних послуг, а саме: принцип системності, принцип законності, принцип координації, принцип достатності, принцип забезпеченості, принцип використання інформаційних технологій, принцип зворотного зв'язку, принцип тривалості. Розкрито їхні особливості та показано, що вони складають єдиний злагоджений механізм, формують потужне мотиваційне середовище, що забезпечує ефективність реформ. Показано, що дотримання ключових принципів дає підстави для застосування широкого спектру методів вдосконалення системи надання державних послуг. Серед таких автором визначено методи стандартизації, регламентації, оптимізації, автоматизації, реінжинірингу, що є перспективою подальшого дослідження даної проблематики. Зарубіжний досвід вдосконалення державних послуг свідчить, що важливою умовою ефективного публічного управління $\epsilon$ регламентація і стандартизація його основних процесів та результатів, що може мати застосування в Україні та суттєво сприятиме ефективності функціонування системи державних послуг. 
Ключові слова: послуга, публічна послуга, державна послуга, муніципальна послуга, адміністративна послуга, соціальна послуга.

Stolar Vadym Mihailovich Postgraduate student of Public Administration Department of the Taras Shevchenko National University, Volodymyrska St., 64/13, Kyiv, 01601, tel.: (044) 239-31-12, e-mail: sto-nauk@ukr.net, https://orcid.org/0000-0003-1493-6830

\title{
PRINCIPLES FOR IMPROVING THE PUBLIC SERVICE SYSTEM (INTERNATIONAL EXPERIENCE)
}

\begin{abstract}
It is shown that in modern models of public administration, which are based on the idea of a service state, the role of the institution of public services is growing. It is noted that modern governments are looking for various ways to improve the process of providing public services, and the state of Ukraine is looking for its own way to modernize public administration and improve the public service system. The author warns that a successful version of the mechanism of providing public services in one country is not always successful in another country. Therefore, the state reform of administrative services in Ukraine should not blindly copy foreign experience, but take into account the fundamental principles of modernization and carefully analyze the consequences. The author is convinced that the experience of countries with established democratic values is very important for Ukraine. After all, in such political systems a special role is given to the institution of public services, and the relations between the state and society are transparent and equal. In this regard, the author has chosen the practice of reforming public services in the United States, Canada, Australia, New Zealand, Western Europe. A theoretical study of the essence of the concept of "service". The principles and methods of improving public services are analyzed. The following basic principles of reforming the public service system are identified, namely: the principle of systematization, the principle of legality, the principle of coordination, the principle of sufficiency, the principle of security, the principle of using information technology, the principle of feedback, the principle of duration. Their peculiarities are revealed and it is shown that they form a single coordinated mechanism, form a powerful motivational environment that ensures the effectiveness of reforms. It is shown that compliance with key principles provides grounds for the application of a wide range of methods to improve the system of public services. Among such the author identified methods of standardization, regulation, optimization, automation, reengineering, which is a prospect for further study of this issue. Foreign experience in improving public services shows that an important condition for effective public administration is the regulation and standardization of its main processes and results, which can be used in Ukraine and significantly contribute to the efficiency of the public service system.
\end{abstract}

Keywords: service, public service, state service, municipal service, administrative service, social service. 
Постановка проблеми. У сучасних моделях державного управління, які спираються на ідею сервісної держави, зростає роль інституту державних послуг, що спонукає уряди шукати різноманітні способи удосконалення процесу надання державних послуг. Україна лише стала на подібний шлях модернізації державного управління. Відтак, є потреба вивчення зарубіжного досвіду. Було б помилково вважати, що той чи інший національний варіант механізму надання державних послуг буде однаково ефективним для будьякої країни. Державна реформа в Україні, в рамках якої розглядаємо проблеми вдосконалення державних послуг, не має калькувати зарубіжний досвід, але враховувати основоположні принципи модернізаційних процесів. Тому, цікавим і корисним для вивчення можливості впровадження такого досвіду у пострадянських країнах $\epsilon$ приклади країн 3 усталеними демократичними цінностями. У таких політичних системах постулюється особлива роль інституту державних послуг, а відносини між державою та суспільством - як рівнозначні. Високі досягнення у реформуванні державних послуг у США, країнах Західної Свропи та деяких азіатських країнах, дають підстави для глибинного аналізу такого досвіду.

Аналіз останніх досліджень i публікацій. У вітчизняній науці державного управління низка дослідників здійснили глибинний аналіз проблематики державних послуг. Зокрема, питання щодо шляхів підвищення якості надання адміністративних послуг в Україні розкрито Н.С. Грабаром [1]. Державне управління та європейська інтеграція досліджуються Д. В. Вітер, Л. Л. Прокопенко, О. М. Руденко, Л. М. Усаченко та іншими [3-8]. Важливі для нас дослідження, які здійснює Національний інститут стратегічних досліджень при Президентові України щодо нормативно-проектного забезпечення розвитку інформаційного суспільства в Свропейському Союзі. Зокрема, Ю. П. Шаров та I.А. Чикаренко вивчали європейські стандарти публічного управління [4]. Проте, наявність великої кількості праць з даної тематики не забезпечує актуальне розуміння основоположних принципів та методів вдосконалення державних послуг у контексті здійснюваної реформи державного управління, що може забезпечити дослідження досвіду країн Західної Свропи у контексті даного питання.

Мета статті. Дослідити принципи та методи вдосконалення державних послуг у країнах Західної Європи та аргументувати, що досвід цих країн може бути застосований в Україні.

Виклад основного матеріалу. Вивчення зарубіжного досвіду вдосконалення процесу та результатів надання державних послуг, не зважаючи на національне різноманіття підходів [1; 2; 3-8], дозволило виокремити декілька основоположних принципів, на яких грунтуються більшість спроб успішного реформування. Звернімо увагу на такі: принцип системності, принцип законності, принцип координації, принцип достатності, принцип забезпеченості, принцип використання інформаційних технологій, принцип зворотного зв'язку, принцип тривалості. 3 метою оцінки корисності 
їх адаптації до українського сьогодення зупинимось на розкритті окремих принципів детальніше.

Принции системності наголошує на тому, що державні послуги є складним явищем, a їх удосконалення повинно враховувати усі його складові: об'єкта і суб'єкта надання послуги, результат їхньої взаємодії (своєрідний «продукт»). Звісно, державна послуга визначається не лише названими складовими, проте змушує нас приймати іï як системне явище i застосовувати до процесу модернізації системний підхід. Система державних послуг є інтегрованою сукупністю усіх елементів, у тому числі, процесів, при чому кожен структурний елемент відповідає за загальну стабільність, цілісність та розвиток [2, с. 34]. Пропонуємо розглядати структуру системи державних послуг як сукупність кількох підсистем: інституційної, комунікативної, нормативної, процедурно-процесуальної.

Принции законності показує, що успішна модернізація державного управління розпочинається із законодавчих процедур. У країнах Європейського Союзу питання надання публічних послуг населенню $\epsilon$ настільки важливим, що їх регулювання включено до законодавства Свропейського Союзу, зокрема до Договору про функціонування Європейського Союзу (гл. 3 «Послуги» розд. 4) та до Протоколу № 26 «Про послуги загального інтересу» [5, с. 73]. На цій основі у країнах Європейського Союзу створено відповідну правову базу, розроблено концепції та програми, які не тільки визначають загальні засади діяльності державних органів щодо надання публічних послуг населенню, але й визначають та закріплюють стандарти якості їх надання [4; 13].

Принции координації означає, насамперед, необхідність керування реформаційними заходами одним уповноваженим державним органом, що забезпечить узгодженість та послідовність дій та визначену за них відповідальність. Як правило, таку роль виконують інституції високого управлінського рівня, які забезпечують належний рівень координації заходів та взаємодії між учасниками реформаційних процесів. Наприклад, у США таким координаційним центром стала Міжвідомча комісія 3 перегляду діяльності державних установ.

Принции достатності передбачає, що в результаті вдосконалення інституту державних послуг буде визначений необхідний об'єм ресурсів для реалізації такої послуги. Модернізація державного управління у більшості країн передбачає делегування державою виконання послуг тим чи іншим уповноваженим інституціям. На надання державних послуг можуть бути уповноважені: безпосередньо органи виконавчої влади та ii структурні підрозділи; підвідомчі бюджетні установи; наглядові організації та інспекції, що входять в систему відповідних міністерств і відомств; недержавні структури; муніципальні органи влади [4]. Мінусом є те, що у результаті, може виникнути масштабний ринок надлишкових (a, відтак, фіктивних) державних послуг. Також існує небезпека дефіциту державних послуг, які необхідні громадянам. 
Принщип забезпеченості процесу вдосконалення державних послуг має важливе інституційне значення $\mathrm{i}$ вимагає забезпечення проведення зазначених реформ розгалуженою мережею дослідних, консультаційних, навчальних та інших підтримуючих структур. Багато країн, що проводять реформи в сфері державних послуг, намагаються одночасно розвивати відповідні елементи інфраструктури на підтримку системи надання державних послуг. Інфраструктура складається 3 мережі організацій і установ, які проводять дослідження, формують інформаційну базу даних, надають консультації споживачам послуг, забезпечують навчання державних службовців, i таким чином оптимізують процес надання державних послуг. У Канаді діють телефонізовані центри «1-800 Канада» (інформують населення про необхідну послугу), «Центри доступу» (консультують підприємців-початківців, а також надають значну кількість державних послуг і працюють за принципом «єдиного вікна»). У Польщі в 2002 р. було створено Інформаційний центр державної служби, який забезпечує доступ пересічних громадян і самих державних службовців до інформації про види державних послуг, сфери діяльності окремих державних органів і установ. У Греції була розроблена «Програма якості», покликана об'єднати в єдину інформаційну мережу усі консультаційні центри 3 державних послуг [див.: $5 ; 12 ; 13]$.

Принщип використання інформаційних технологій, без якого не обходяться більшість сучасних модернізаційних процесів, повинен супроводжувати також і процеси вдосконалення інституту державних послуг. Користь його застосування полягає в можливості збільшення доступу споживачів до державних послуг, а також інформації про них. Він $\epsilon$ потужним стимулом до впровадження нових підходів, механізмів і принципів у сфері управління. Електронний доступ до основних державних послуг у міжнародній практиці вважається одним із найважливіших елементів електронного урядування. Країни ухвалили власні програми інформатизації, впроваджують «електронний уряд» («e-government»), відкриваються урядові веб-портали, де кожен може отримати будь-яку інформацію про діяльність владних інститутів та інші послуги. Ефективним способом оптимізації надання державних послуг є організація «єдиного офісу» («one-stop-shop»), який дозволяє громадянам швидко, без зайвих затрат часу та пересувань отримувати послуги від держави.

Особлива увага наділяється принщиипу зворотного зв'язку, який забезпечує моніторинг проблем та успіхів у сфері надання послуг та здійснює практичну допомогу у формуванні стратегії подальшого вдосконалення державних послуг з урахуванням потреб і очікувань споживачів [6-7]. У США в рамках загальнонаціональної програми «Перший пріоритет - клієнти» проводиться моніторинг оцінки якості послуг, вивчення очікувань споживачів. Поряд з цим проводяться регулярні опитування серед державних службовців, які безпосередньо контактують 3 населенням в процесі надання послуг, з метою виявлення недоліків і збору пропозицій для досягнення рівня 
стандартів якості послуг, що надаються приватним сектором [5]. В Австралії інформаційна система «Canberra-Connect» передбачає форми, які можуть заповнити бажаючі запропонувати шляхи вдосконалення надання кожного окремо взятого виду послуг. Отже, цей принцип має важливе стратегічне значення у сфері модернізації державного управління, оскільки дозволяє вчасно реагувати на поточні проблеми та оцінювати результати проведеної роботи.

Принщип тривалості. Як і будь-який реформаційний процес, зміни у сфері державних послуг потребує поступовості, виваженості, що відображається тривалістю у часі та постановкою завдань на довго-, середньо- та короткострокову перспективу. Наприклад, система «Хартї послуг» у Великобританії 1991 р., була розрахована на 10 років, але вдосконалення окремих компонентів цієї системи відбувається й досі [5]. Також в інших країнах СС, і в США, програми з вдосконалення державних послуг мають тенденцію до продовження в часі. Це дуже важливо з точки зору стратегічного управління. Стратегічні цілі постійно корегуються під впливом різних обставин. Тривалість процесу вдосконалення надання державних послуг має декілька важливих пояснень. По-перш, це масштабність поставлених цілей i завдань. По-друге, це необхідність постійного залучення здобутків науково-технічного прогресу. I, по-третє, це велика кількість елементів системи державних послуг, кожен з яких потребує змін та відновлення самої системи. Зокрема, останній чинник пояснює, чому проведення реформ у сфері державних послуг іноді поспішно визначають, як неуспішне та нерезультативне.

Висновки. Цінність і дієвість названих принципів полягає в тому, що вони $\epsilon$ не набором окремих умов та правил, а діють комплексно. Вони складають єдиний злагоджений механізм, формують потужне мотиваційне середовище, що забезпечує ефективність реформ.

Дотримання ключових принципів дає підстави для застосування широкого спектру методів вдосконалення системи надання державних послуг: стандартизації, регламентації, оптимізації, автоматизації, реінжинірингу, що $є$ перспективою подальшого дослідження даної проблематики.

Зарубіжний досвід вдосконалення державних послуг свідчить, що важливою умовою ефективного публічного управління $\epsilon$ регламентація i стандартизація його основних процесів та результатів, що може мати застосування в Україні та суттєво сприятиме ефективності функціонування системи державних послуг.

\section{Лimepamypa:}

1. Грабар Н.С. Шляхи підвищення якості надання адміністративних послуг в Україні. Актуальні проблеми держсавного управління. 2015. № 1. С. 33-39.

2. Гинтова М.А., Жулин А.Б., Костырко А.А., Плаксин С.М., Синятуллина Л.Х. Реинжиниринг государственных услуг, комплексных сфер государственного 
регулирования: вопросы методологии. Bопросы государственного и муниципального управления. 2012, № 1. С. 7 - 25 .

3. Державне управління та європейська інтеграція: еволюція поглядів: [навч. посіб.] / Д. В. Вітер, Л. Л. Прокопенко, О. М. Руденко, Л. М. Усаченко. К.: ТОВ «НВП «Інтерсервіс», 2013. 153 с.

4. Європейський досвід нормативно-проектного забезпечення розвитку інформаційного суспільства: висновки для України. Аналітична доповідь. НІСД. К., 2014. $76 \mathrm{c}$

5. Тихонова Д.С. Зарубіжний досвід надання адміністративних послуг. Право $i$ Безпека. 2014. № 4. С. 70-75.

6. Шаров Ю. П. Чикаренко I.А. Європейські стандарти публічного управління: проекція на муніципальний рівень. Державне управління та місиеве самоврядування. Збірка наукових пращь. Дніпро. ДРІДУ НАДУ, 2010. Вип. 1 (4). С. 295 - 304.

7. Шаров Ю.П., Маматова Т.В. Міжнародні практики громадського моніторингу надання публічних послуг. Аспекти публічного управління. 2013. № 2. С. 69-76.

8. Шереметьєва Л. А., Беца І.І. Концептуальні підходи, типи та види державних послуг в Європейському Союзі та в Україні: порівняльний аналіз. URL: http://www.academy.gov.ua/ej/ej12/txts/10slaupa.pdf.

9. Шульга М. А., Коновалова М. В. Інновації в державному управлінні як умова розбудови сервісної держави. Вісник Київського національного університету імені Тараса Шевченка. Державне управління 1 (1) 2014. С. 97-100.

10. Щербаківська Л.М. Концептуалізація державних послуг. Вісник Академії митної служби Украӥни. Серія : Державне управління. 2014. № 2. С. 120-124.

11. Mystery Shopping Providers Association Europe (MSPA Europe). URL: http://mspa_eu.org/en/news.html.

12. Single market for services (White Paper on Services of General Interest, «Services» Directive). URL: http://europa.eu/legislation_summaries/internal_market/single_market_ services/ index_en.htm.

13. UNPD. Good Governance and Sustainable Human Development // Governance for Sustainable Human Development. A UNPD Policy Document. 2002. URL: http://magnet.unpd.org.

\section{References:}

1. Ghrabar N.S. (2015). Shljakhy pidvyshhennja jakosti nadannja administratyvnykh poslugh v Ukrajini [Ways to improve the quality of administrative services in Ukraine]. Aktualjni problemy derzhavnogho upravlinnja - Actual problems of public administration. 1. 3339 [in Ukrainian].

2. Gintova, M.A., Zhulin, A.B., Kostyrko, A.A., Plaksin, S.M., Sinyatullina, L.Kh. (2012). Reinzhiniring gosudarstvennykh uslug, kompleksnykh sfer gosudarstvennogo regulirovaniya: voprosy metodologii [Reengineering of public services, complex spheres of state regulation: questions of methodology]. Voprosy gosudarstvennogo i munitsipalnogo upravleniya - Issues of state and municipal administration. 1.7 - 25 [in Russian].

3. Viter, D. V. , Prokopenko, L. L., Rudenko, O. M., Usachenko, L. M.. Derzhavne upravlinnja ta jevropejsjka integhracija: evoljucija poghljadiv [Public administration and European integration: the evolution of views] (2013) [in Ukrainian].

4. Jevropejsjkyj dosvid normatyvno-proektnogho zabezpechennja rozvytku informacijnogho suspiljstva: vysnovky dlja Ukrajiny [European experience of normative-project support of information society development: conclusions for Ukraine] (2014). Analitychna dopovid.. - Analytical report. [in Ukrainian].

5. Tykhonova D.S. (2014). Zarubizhnyj dosvid nadannja administratyvnykh poslugh [Foreign experience in providing administrative services]. Pravo i Bezpeka - Law and Security. 4. 70-75. [in Ukrainian]. 
6. Sharov Ju. P. Chykarenko I.A. (2010). Jevropejsjki standarty publichnogho upravlinnja: proekcija na municypaljnyj rivenj [European standards of public administration: projection to the municipal level]. Derzhavne upravlinnja ta misceve samovrjaduvannja. Zbirka naukovykh pracj - Public administration and local self-government. Collection of scientific works. 1 (4). 295 304 [in Ukrainian].

7. Sharov Ju.P., Mamatova T.V. (2013). Mizhnarodni praktyky ghromadsjkogho monitorynghu nadannja publichnykh poslugh [International practices of public monitoring of public services]. Aspekty publichnogho upravlinnja - Aspects of public administration. 2. 69-76 [in Ukrainian].

8. Sheremetjjeva L. A., Beca I.I. (2012). Konceptualjni pidkhody, typy ta vydy derzhavnykh poslugh v Jevropejsjkomu Sojuzi ta v Ukrajini: porivnjaljnyj analiz [Conceptual approaches, types and kinds of public services in the European Union and in Ukraine: a comparative analysis]. URL: http://www.academy.gov.ua/ej/ej12/txts/10slaupa.pdf. [in Ukrainian].

9. Shuljgha M. A., Konovalova M. V. (2014). Innovaciji v derzhavnomu upravlinni jak umova rozbudovy servisnoji derzhavy [Innovations in public administration as a condition for the development of the service state]. Visnyk Kyjivsjkogho nacionaljnogho universytetu imeni Tarasa Shevchenka. Derzhavne upravlinnja - Bulletin of the Taras Shevchenko National University of Kyiv. Public Administration 1 (1). 97-100 [in Ukrainian].

10. Shherbakivsjka L.M. (2014). Konceptualizacija derzhavnykh poslugh [Conceptualization of public services]. Visnyk Akademiji mytnoji sluzhby Ukrajiny. Serija : Derzhavne upravlinnja - Bulletin of the Academy of Customs Service of Ukraine. Series: Public Administration. 2. 120-124 [in Ukrainian].

11. Mystery Shopping Providers Association Europe (MSPA Europe) (2015). URL: http://mspa_eu.org/en/news.html [in English].

12. Single market for services (White Paper on Services of General Interest, «Services» Directive) (2014). URL: http://europa.eu/legislation_summaries/internal_market/single_ market_services/index_en.htm. [in English].

13. UNPD. Good Governance and Sustainable Human Development (2002). Governance for Sustainable Human Development. A UNPD Policy Document. URL: http://magnet.unpd.org [in English]. 